\title{
Lean production: experience among Russian organizations
}

\author{
Yu.S. Bakhracheva ${ }^{1, *}$, and Ya.Ya. $\mathrm{Kayl}^{2}$ \\ ${ }^{1}$ Volgograd State University, Prosp. Universitetsky, 100, Volgograd, Russian Federation \\ ${ }^{2}$ Volgograd State Socio-Pedagogic University, Prosp. Lenina, 27, Volgograd, Russian Federation
}

\begin{abstract}
The article gives analysis of the implementation of lean production, one of the basic models of resource management, in the context of the current unstable economic situation in Russia, occurring due to the geopolitical situation in the world. The concept of lean production is defined. The basis for resource management: effective use of available resources, minimization of overall costs, increase profits, maximize the capitalization of the company. Strategic enterprise management based on the optimal allocation of internal resources is the key factor of success. Lean production is widespread in Russia since 2001. However, there are difficulties in the introduction, one reason for which is the "human factor" and the lack of a unified methodology of practical application.
\end{abstract}

\section{Introduction}

The beginning of 2015 was marked for Russia by immersion in a crisis economic condition, informed the aggravated geopolitical situation in the world. In the current environment, it is necessary the rational use of domestic resources. Economic diversification is a complex process that can be implemented through state regulation. However, the role of enterprises is the main and lies in the effective management of private economic resources.

In Russia at the enterprises begins to show interest in possibilities to improve competitiveness and modernization of production through Lean Production. The highest activity is demonstrated by large enterprises employing more than a thousand people located in the Ural or Volga Federal districts relating to the engineering industries, ferrous or non-ferrous metallurgy. This is due to the greater availability of information about the experience of implementing the tools of lean production and the presence of these businesses in the global market: they have to compete with foreign producers, to meet international standards of product quality [1].

\section{The introduction of Lean Production in the Russian economy}

Resource management is a field of scientific knowledge, based on the efficiency of enterprises. The basis for resource management: effective use of available resources, minimization of overall costs, increase profits, maximize the capitalization of the company. One of the main models of resource management is Lean Production, also known as the Toyota Production System. The concept is built on the simultaneous achievement of the following internal purposes, providing the company competitive advantage [2]: - constant reduction of production costs and sales;

- continuous improvement of product quality;

- optimization of the flow of material according to the logic of Just In Time.

The basic idea of Lean Production is to improve the efficiency of enterprise activity from within existing resources through continuous improvement of all processes. In Russia Lean Production appeared relatively recently, but already managed to get support at the highest level. Dmitry Medvedev at meeting of Commission for modernisation in 2011 noted that to enhance the competitiveness of domestic enterprises and their effectiveness it is essential to develop production systems. In this sense he's very interested in the concept of "Lean Production and Lean Thinking" [1].

In 2001, he was first recorded working example of introducing the concept of Lean Production in domestic practice at the plant of the Ford Motor Company in Vsevolozhsk, Leningrad region. Currently, this model of resource management applied in all the sectors of the Russian economy.

\section{The results of the implementation of Lean Production in industry}

There is an assumption that the concept of lean production - Lean Production is more applicable for industrial companies $[3 ; 4 ; 5]$. The tools of Lean Production implementing the enterprise's fundamental, existing from the Soviet era (for example, OJSC KAMAZ, Engels instrument-making association "Signal", GAZ group, etc.). Doing this foreign enterprise, which came to the Russian market, is already actively using this model (e.g., Ford Motor Company,

Corresponding author: bakhracheva@yandex.ru

C) The Authors, published by EDP Sciences. This is an open access article distributed under the terms of the Creative Commons Attribution License 4.0 (http://creativecommons.org/licenses/by/4.0/). 
Toyota Motor Manufacturing, group of companies NCC, Volkswagen group, etc.). Thus, there is no uniform method of introducing the concept in Russian companies, which is one of the reasons for unsuccessful attempts of development of the model. However, the implementation of lean production is very high. For example, in the sector of oil production the effectiveness of implementation of Lean Production:

- cost reduction by $30 \%$ (annual savings of 11.5 million rubles);

- reduced work in progress by 50\% (elimination of downtime of wells - additional income of 130 million rubles per year);

- the release of the production area by $30 \%$;

- the release of labour by $25 \%$ (reduced labor cost more than 1.3 million rubles a year).

In the automotive industry (OJSC KAMAZ, GAZ group) resulted in reduction of costs by $30 \%$ (saving 65 million rubles per 1 week).

\section{Analysis of experience of implementation of Lean Production in the service sector}

Typical examples applying the concept of Lean Production are a giant organization covering a network of its branches throughout Russia, such as JSC "Sberbank", JSC "Russian Railways", "Russian Post". At the moment they are at different stages of implementation of lean production principles. Quality restart patterns, covering the whole country, is a difficult and complex process [6].

Sberbank since 2008 quite successfully it takes place. Within the first transformation after his appointment to the post of Chairman of the Board German Gref announced the creation of Sberbank's production system, which is based on the principles of lean manufacturing. Production system of Sberbank is focused on increasing customer satisfaction, improving operational efficiency, increasing motivation and increase employee satisfaction [7]. The starting action towards becoming system involved the formation of working groups and invitation specialist, with experience of working in a company applying the tools of Lean Production. The whole existing system of the Bank was dismantled to detail as part of the implementation of Lean Production, strategy of development of Bank till 2014 it is Noteworthy that in the initial stages, productivity growth was about $25 \%$ and subsequently increased. The principles of production system of Sberbank was successfully set in the key areas of the Bank, improving efficiency by $30-50 \%$ [8].

Achieving high performance was the result of a number of projects [8]:

- transformation of the retail network. Developed and implemented a new model of working implemented flexible schedules, developed a new incentive system tying the employees ' income to sales results and service quality;

- optimization of work with small businesses. By freeing up time were introduced the role of the client managers, who are tasked with quality customer service;
- standardization and optimization of work of accounting departments. Standards have been created for each operation, implemented a mechanism to manage the workload of employees;

- development and implementation of standards and their continuous improvement;

- creation of the methodology of "Do-it-yourself step by step".

The main objective of the Sberbank's development strategy until 2018 as part of the production of the system is its widespread and successful application.

JSC "Russian Railways" and "Russian Post" has not yet achieved such considerable success as a savings Bank, but are actively implementing Lean Production. One of the steps to becoming Lean Production on the railway was the project "Improving the organization of technology development". At year end, the economic effect of innovations in monetary terms amounted to more than 7.5 million rubles. [9, 10, 14].

Achieved the following technical results:

- reduced time for manufacturing operations;

- minimization of the total idle time of the transit of the carriage on the tracks of stations;

- reduction of irrational use of locomotives as well as downtime of trains awaiting processing.

"Russian Post" began to develop the concept of lean production since the end of 2013. The guidance was adopted a number of measures:

- daily morning conference calls with affiliates;

- create normal working conditions for customs officials;

- optimization of mainline traffic;

- the decline in the proportion of agents in favor of the conclusion of direct contracts;

- creation of integrated logistics unit (appeared obselescence direction of transport and sorting, as well as new patterns - unit planning and the unit for work with claims);

- create a new sorting center in Vnukovo (to unload Moscow), purchased Italian equipment - automated sorting.

Implemented activities provoked an increase in efficiency, bringing the company to the next level of development [11]:

- the volume of international mail, compared to 2012 increased by 4 times;

- over half the share of agents has declined from $75.7 \%$ to $15 \%$, while rates decreased by about $15 \%$ at the expense of margin, had the agents trucking: $2013-9$ contractors, the rate $40,86 \mathrm{RUB} / \mathrm{km}, 2014-32$ contractor, 27,28 tariff RUB./km;

- in 2014, the savings on gas logistics amounted to 900 million rubles - about $11 \%$ of the budget mainline traffic (including repairs);

- all international mail is processed by the Moscow center at the Vnukovo airport, in Moscow arrives about $70 \%$ of mail (up to $95 \%$ ), while the remaining $30 \%$ come to Kazan, Yekaterinburg and Vladivostok;

- in 2014, the volume of parcels delivered has increased 1.6 times compared to 2012, average delivery time within two years decreased from 90 to 14 days, the monthly number of written complaints decreased from 250000 to $20000-40000$. 


\section{Problems of implementation of Lean Production at the Russian enterprises}

According to experts, the main problem in the implementation of Lean Production is "the human factor" [12], significantly affect the realization of the ideology of lean manufacturing.

Let's consider the main reasons for the rejection of innovations:

- fear of worsening working conditions, pay, load increases, etc.;

- lack of conviction that change from confusion over the objectives of the change;

- the surprise prepared by the operations manual, important changes;

- fear of failure to adapt to changes, increase efficiency of work in the new situation;

- violation of the established order, habits and relationships;

- lack of respect and trust to the person conducting the change.

It is also possible to allocate three basic principles of the procedure:

- fiercer all resist change are exactly those who most need them;

- resistance to change - the result of incorrect techniques of their implementation;

- passive opposition to change is often associated with past experiences: people who have already survived a lot of reorganizations that had not benefited, are particularly suspicious.

For successful introduction of system "Lean Production" it is necessary to use principles of participation, in other words, worker participation in enterprise management. Participate is the participation of the employees in the management of the company along with its owners, employers, professional stewards (managers and others).

Most effectively these principles can be implemented through: inclusion of labour collective of the enterprise in the decision-making processes; employee participation in the profits (income) of enterprises; the availability of equity ownership among employees through equity (or shares) of the company.

In the leading foreign countries of Japan, Germany, Sweden and others, all of these principles has been successfully applied.

In Russia today the practice of implementing the principles of participation at the enterprises is still lacking. This is evidenced by open sources of information. Usually workers of the enterprise (organization) work according to clearly defined rates and pay systems, stimulating their personal performance. Ordinary employees usually do not get anything from the profits of the enterprise.

Today in industrially developed countries (Norway, Sweden, France, Japan, Denmark, USA, etc.) in enterprises has a program of employee participation in stock ownership [13]. The advantage of this practice is that it does not require additional costs from an employee, but can provide income in the form of dividends. In many Western countries it is recommended to concentrate in the hands of managers and external investors is not more than $30 \%$ stake in the company.

Experience shows that the introduction of such a system within two years leads to productivity growth on the average on $10-15 \%$ [8]. So in Japan, productivity in companies that implement plans of employee participation in the share capital, $7 \%$ higher than those where workers do not own shares in [13].

Of course, to introduce the basic principles of participarii it is necessary to regulate at the state level and the development of corresponding normative-legal acts. To achieve a good economic effect and improve the performance of employees, you need to:

1) the adoption of Lean Production at the government level and the state regulation of activities of enterprises applying this model of resource management. In the Republic of Tatarstan, the first among the subjects of the Russian Federation, was adopted at the national level and is functioning successfully long-term target program "Implementing methods of "Lean production" for 20122013". In 2013 economic effect of the introduction of this model of resource management at national enterprises amounted to more than RUB 6 billion in the first nine months of 2014, 3 billion rubles;

2) the involvement of foreign consultants for implementation of Lean Production and training of domestic consultants;

3) the implementation of advocacy activities with objectives, tasks and principles of Lean Production to all levels of organisational structures of enterprises.

The paragraphs is far from complete, but the basic complex of measures on transition of Russian enterprises to modern Japanese organizational technology.

\section{Conclusion}

In conclusion, it is worth noting that you should carefully and thoughtfully apply to the use of lean manufacturing at the enterprise, to carry out the mandatory preliminary assessment of the feasibility of implementation. Moreover, currently there is active development of information automation solutions to lean manufacturing, the use of which, together with traditional management systems can greatly help to optimize the implementation of lean production. Summing up the results of the systematization of the results of lean implementation in various sectors of the Russian economy; we can distinguish the following main conclusions and results:

1. The future of national economic sectors is directly dependent on the actions made in the current crisis. The strategic management of enterprises based on the optimal allocation of domestic resources are the main factor of success.

2. Lean Production is a effective concept to achieve growth and competitiveness in the market in the conditions of unstable economic development.

3. There are successful examples of the development of the concept both in industry and in services. 
4. Lean production is widespread in Russia since 2001, However, there are difficulties in the introduction, one reason for which is the "human factor" and the lack of a unified methodology of practical application.

This work was supported by the Russian Foundation for Humanities (project № №16-12-34014).

\section{References}

1. O.S. Vikhansky, Expert-Ural, 7(270), 35 (2007)

2. E.S. Balashova, V.N. Yuriev, Economic mechanism and tools of the resource management for industrial enterprise (Publisher Polytechnic University, Saint Petersburg, 2014)

3. Imai M. Kaizen, The key to Japan's competitive success (Alpina Publisher, Moscow, 2014)

4. J. Liker, 14 management principles from the world's greatest manufacturer (Alpina Publisher, Moscow, 2013)

5. T. Ohno, Toyota production system. Beyond largescale production (Institute for strategic studies, Moscow, 2013)

6. Digest Mc Kinsey, New trends in management (Alpina Business Books, Moscow, 2010)

7. Sberbank Production System. http://www.leanforum.ru/content/files/library/PSS.p df.

8. Sberbank's Development Strategy until year 2018. http://www.sberbank.ru/common/img/uploaded/files $/ \mathrm{S}$.

9. Ya.Ya. Kayl, Yu.S. Bakhracheva, Science Journal of Volgograd State University. Technology and Innovations, 3(18), 19-25 (2015). DOI: http://dx.doi.org/10.15688/jvolsu10.2015.3.2.
10. R.S. Medvedev, Yu.S. Bakhracheva, Science Journal of Volgograd State University. Technology and Innovations, 3(12), 93-97 (2014). DOI: 10.15688/jvolsu10.2014.3.11.

11. How did the new management change the "Post Office of Russia". http://www.leanforum.ru/library/r1/2386.html.

12. Modern concepts of production management: Lean Production.http://www.remmag.ru/admin/upload_da ta/remmag/07- 5/RoundTable.pdf.

13. I. Jac, J. Sedlar, A.A. Zaytsev, A.V. Zaytsev, E \& M: Ekonomie a Management, 16, 3, 75-84 (2013)

14. Ju.S. Bahracheva, E.V. Akatova, Bulletin of Volgograd State University. Series 10: Innovation activities, 5, 6-11 (2014). DOI: http://dx.doi.org/10.15688/jvolsu10.2014.5.1.

15. Ju.V. Gaponenko, Bulletin of Volgograd State University. Series 10: Innovation activities, 1, 6-10 (2014)

16. The age of lean production - Lean manufacturing, Livshits $V$. national server of modern prose Prose.ru. http://proza.ru/2007/03/25-282.

17. L.M. Semenova, V.B. Khlebnikov, Yu.S. Bakhracheva, Science Journal of Volgograd State University. Technology and Innovations, 2, 49-56 (2013). DOI: 10.15688/ jvolsu10.2013.2.7.

18. L.M. Semenova, V.B. Khlebnikov, Yu.S. Bakhracheva, S.V. Semenov, Science Journal of Volgograd State University. Technology and Innovations, 7, 120-126 (2012)

19. Russian Statistical Yearbook 2015: Statistical Compilation (Rosstat Publ., Moscow, 2015)

20. The Strategy of Railway Transport Development in the Russian Federation Till 2030 (2008) 